\title{
Respon Beberapa Galur Padi Smart Hasil Mutasi Padi Lokal Aceh Dengan Teknologi Sinar Gamma Terhadap Xanthomonas Oryzae Pv. Oryzae Penyebab Penyakit Hawar Daun Bakteri
}

\author{
${ }^{1}$ Fajar, ${ }^{* 2}$ Lukman Hakim, ${ }^{2}$ Marlina, dan ${ }^{3}$ Efendi \\ 1) Alumni Fakultas Pertanian Universitas Syiah Kuala \\ 2) Jurusan Proteksi Tanaman Fakultas Pertanian Universitas Syiah Kuala \\ 3) Jurusan Agroteknologi Fakultas Pertanian Universitas Syiah Kuala \\ Jl. Tgk Hasan Krueng Kalee No. 3 Banda Aceh Kopelma Darussalam \\ *2e-mail korenspondensi : $\underline{\text { hk } \text { hakiem@unsyiah.ac.id }}$
}

\begin{abstract}
This study aims to determine the response of several lines resulting from the radiation mutation of Aceh's local rice to Xanthomonas oryzae pv. oryzae causes bacterial leaf blight in rice. The experiment was designed according to a randomized block design (RBD) with 3 replications. The total of 18 Aceh local rice radiation mutations tested, including; Simeulu (USKSnbr-M04-238-074-001), Sisambay (USK-Snbr-M04-238-081-002), Sanberasi (USK-Snbr-M04-238-017-023), Siteluk (USKSnbr -M04-238-092-097), Sibahak (USK-Snbr-M04-238-073-079), Sulutan Unsrat-1, Sibabus (USK-Snbr-M04-238-110-116), Simuara (USK-Snbr-M04-238-091-097B), Siluan (USK-Snbr-M04-238-058-064), Sikuala (USK-Snbr-M04-238-114-120), UF5, Sibuluh (USK-Snbr-M04- 238-V1B-017), Sialavan (USK-Snbr-M04-238-051-057E), Snb, UF 1, IRBB, 118- (Snbr-238-112-118180-11), 119- (Snbr-238-112-119-160-10). The observed variables include; increase in plant height, number of tillers per clump, number of panicles, percentage of filled grain, percentage of empty grain, harvest index, weight of well-laden grains per clump and yield per hectare. The results showed that the difference in the response of 18 lines resulting from the mutation of local Aceh rice radiation to bacterial leaf blight had a significant difference in height increase and the number of tillers and the number of panicles. In the observation that the percent of grain contains, the percent of empty unhulled rice, the yield per clump and the production per hectare, the effect of blight is not significant.
\end{abstract}

Keywords: Aceh local rice, bacterial leaf blight, gamma ray mutations,

Abstrak. Penelitian ini bertujuan untuk mengetahui respon beberapa galur hasil mutasi radiasi padi lokal Aceh terhadap Xanthomonas oryzae $p v$. oryzae penyebab penyakit hawar daun bakteri pada padi. Percobaan dirancang menurut Rancangan Acak Kelompok (RAK) dengan 3 ulangan. Padi lokal Aceh hasil mutasi radiasi yang diuji sebanyak 18 galur, meliputi; Simeulu (USK-Snbr-M04-238-074-001), Sisambay (USK-Snbr-M04-238-081-002), Sanberasi (USK-Snbr-M04-238-017-023), Siteluk (USK-Snbr-M04-238-092-097), Sibahak (USK-Snbr-M04-238-073-079), Sulutan Unsrat-1, Sibabus (USK-Snbr-M04-238-110116), Simuara (USK-Snbr-M04-238-091-097B), Siluan (USK-Snbr-M04-238-058-064), Sikuala (USK-Snbr-M04-238-114120), UF5, Sibuluh (USK-Snbr-M04-238-V1B-017), Sialavan (USK-Snbr-M04-238-051-057E), Snb, UF 1, IRBB, 118-(Snbr238-112-118-180-11), 119-(Snbr-238-112-119-160-10). Peubah yang diamati meliputi; pertambahan tinggi tanaman, jumlah anakan per rumpun, jumlah malai, persentase gabah berisi, persentase gabah hampa, indeks panen, berat gabah bernas per rumpun dan hasil produksi per hektar. Hasil penelitian menunjukkan bahwa perbedaan respon 18 galur hasil mutasi radiasi padi lokal Aceh terhadap penyakit hawar daun bakteri memiliki perbedaan yang signifikan pada pertambahan tinggi dan jumlah anakan serta jumlah malai. Pada pengamatan persen gabah berisi, persen gabah hampa, hasil panen per rumpun dan produksi per hektar, pengaruh penyakit hawar daun tidak signifikan.

Kata kunci: padi lokal Aceh, hawar daun bakteri, mutasi sinar gamma,

\section{PENDAHULUAN}

Tingkat kerugian hasil panen padi yang ditimbulkan oleh penyakit Hawar Daun Bakteri (HBD) pada musim hujan dapat mencapai 21-36 \% dan sebesar 18-28\% pada musim kemarau. Luas serangan penyakit ini pernah mencapai lebih dari 74 ribu ha, dan 16 ha diantaranya mengalami puso. Di negara-negara penghasil padi seperti Indonesia, HDB termasuk penyakit yang sangat penting (Ou,1985; Hifni dan Kardin 1998;Suparyono dkk, 2004). Seiring dampak yang sangat merugikan ini, para pemulia tanaman padi mendapat tantangan berat untuk mengatasi masalah tersebut. Upaya yang dilakukan antara lain pemuliaan tanaman padi melalui teknik mutasi dengan radiasi sinar gamma. Hal ini telah dilakukan pada beberapa jenis padi lokal Aceh.

Laju konsumsi beras pada tahun 2017 mencapai 114,6 kg per kapita per tahun dengan jumlah penduduk 261,89 juta jiwa, sehingga jumlah konsumsi beras nasional mencapai 33,47 juta ton (BPS, 2018). Sementara itu Anggraini $d k k$ (2013 mengemukakan bahwa dari tahun ke tahun laju peningkatan kebutuhan beras untuk pangan lebih cepat dari pertumbuhan produksi pangan yang tersedia. Menyikapi laju konsumsi yang relatif tinggi ini, maka peningkatan produksi beras nasional menuju tercapainya swasembada senantiasa menjadi program prioritas pembangunan pertanian di Indonesia. Namun demikian, seringkali masih terkendala oleh adanya pengaruh faktor cekaman lingkungan termasuk cekaman biotik. Penyakit Hawar Daun Bakteri (HDB) yang disebabkan oleh bakteri Xanthomonas oryzae pv. oryzae (Xoo) merupakan salah satu faktor cekaman biotik yang dapat menurunkan 
Fajar, Lukman Hakim, Marlina, dan Efendi. Respon Beberapa Galur Padi Smart Hasil Mutasi Padi Lokal Aceh Dengan Teknologi Sinar Gamma Terhadap Xanthomonas Oryzae Pv. Oryzae Penyebab Penyakit Hawar Daun Bakteri

produktivitas padi (Ogawa, 1993). Penyakit ini telah dilaporkan sebagai salah satu penyakit utama pada tanaman padi di negara penghasil padi, termasuk di Indonesia. Serangan HDB di Indonesia menyebabkan kerugian hasil panen sebesar 21-36\% pada musim hujan dan sebesar 18-28\% pada musim kemarau.

Salah satu upaya untuk mengatasi gangguan penyakit HDB yang disebabkan oleh bakteri Xanthomonas oryzae pv. oryzae (Xoo) adalah menggunakan tanaman yang tahan terhadap gangguan penyakit termasuk penyakit HDB. Upaya ini dapat ditempuh melalui kegiatan pemuliaan yang dapat dilakukan antara lain dengan mutasi genetik. Mutasi genetik tanaman dapat diinduksi menggunakan mutagen seperti radiasi sinar gamma.

Radiasi sinar gamma dapat menginduksi dan meningkatkan nutrisi pada padi, sehingga selain dapat meningkatkan ketahanan tanaman terhadap serangan patogen, juga dapat memperbaiki kualitas beras dan sifat agronomis, peningkatan asam amino total, antioksidan, dan klorofil pada mutan padi yang telah diradiasi dengan sinar gamma (Song $d k k$., 2012). Menurut Sudir $d k k$. (2012) penggunaan varietas tahan dinilai sebagai cara yang efektif mengendalikan HDB. Berkaitan dengan itu perlu dilakukan penelitian yang bertujuan untuk mengetahui respon beberapa galur hasil mutasi radiasi padi lokal Aceh terhadap Xanthomonas oryzae pv. oryzae penyebab penyakit hawar daun bakteri pada padi.

\section{Tempat dan Waktu Penelitian}

\section{METODE PENELITIAN}

Penelitian ini dilaksanakan pada bulan Juli sampai November 2017 di Rumah Kaca Kebun Percobaan Fakultas Pertanian, Laboratorium Teknologi Benih Program Studi Agroteknologi, Laboratorium Ilmu Penyakit Tumbuhan Program Studi Proteksi Tanaman Fakultas Pertanian, dan Laboratorium Biologi Fakultas Keguruan dan Ilmu Pendidikan Universitas Syiah Kuala Banda Aceh.

\section{Alat dan Bahan}

Alat yang digunakan dalam penelitian ini adalah cangkul, pot ukuran $14 \mathrm{~kg}$, timbangan analitik, petridish, tabung reaksi, autoclave, erlenmeyer, pinset, jarum ose, micro pipet, inkubator, spektrofotometer, kertas label, kertas buram, spidol permanen, meteran, penggaris dan moisture meter. Sedangkan bahan yang digunakan dalam penelitian ini adalah hasil mutasi radiasi padi lokal Aceh sebanyak 18 galur, Inokulum bakteri Xanthomonas oryzae pv. oryzae, NA, aquades, tanah, pupuk kandang, pupuk Urea, KCl, SP-36, dan air.

\section{Rancangan Percobaan}

Penelitian ini menggunakan metode Rancangan Acak Kelompok (RAK) satu faktor dengan 18 perlakuan dan 3 ulangan. Setiap perlakuan menggunakan 2 unit tanaman sampel. Perlakuan yang dicobakan adalah beberapa galur hasil mutasi radiasi padi lokal Aceh yang diinokulasi dengan bakteri Xanthomonas oryzae pv. oryzae sebagaimana tertera pada Tabel 1 .

Tabel 1. Galur Hasil Mutasi Radiasi Padi Lokal Aceh yang Diuji

\begin{tabular}{cl}
\hline No & \multicolumn{1}{c}{ Nama Mutan } \\
\hline 1 & Simeulu (USK-Snbr-M04-238-074-001) \\
2 & Sisambay (USK-Snbr-M04-238-081-002) \\
3 & Sanberasi (USK-Snbr-M04-238-017-023) \\
4 & Siteluk (USK-Snbr-M04-238-092-097) \\
5 & Sibahak (USK-Snbr-M04-238-073-079) \\
6 & Sulutan Unsrat-1 \\
7 & Sibabus (USK-Snbr-M04-238-110-116) \\
8 & Simuara (USK-Snbr-M04-238-091-097B) \\
9 & Siluan (USK-Snbr-M04-238-058-064) \\
10 & Sikuala (USK-Snbr-M04-238-114-120) \\
11 & UF5 \\
12 & Sibuluh (USK-Snbr-M04-238-V1B-017) \\
13 & Sialavan (USK-Snbr-M04-238-051-057E) \\
14 & Snb \\
15 & UF 1 \\
16 & IRBB \\
17 & $118-($ Snbr-238-112-118-180-11) \\
18 & $119-($ Snbr-238-112-119-160-10) \\
\hline
\end{tabular}


Fajar, Lukman Hakim, Marlina, dan Efendi. Respon Beberapa Galur Padi Smart Hasil Mutasi Padi Lokal Aceh Dengan Teknologi Sinar Gamma Terhadap Xanthomonas Oryzae Pv. Oryzae Penyebab Penyakit Hawar Daun Bakteri

\section{Pelaksanaan Penelitian \\ Persiapan Tanam}

Media tanam dalam penelitian ini menggunakan tanah yang dicampur dengan pupuk kandang dengan perbandingan 2:1, kemudian dicampur dengan air dan diaduk sampai rata sehingga membentuk tekstur lumpur. Benih padi yang dikecambahkan terlebih dahulu direndam dengan air selama 24 jam. Selanjutnya benih dikecambahkan pada botol yang telah dilapisi dengan tisu yang dibasahi. Setelah radikula muncul, benih sudah siap disemai. Penyemaian dilakukan di dalam tray yang berisi tanah dan pupuk kandang dengan perbandingan 2:1. Sebanyak 60 benih padi dari setiap galur disemai pada masing-masing tray perlakuan.

\section{Penanaman}

Setelah bibit berumur 10 hari di persemaian, dipindahtanamkan ke masing-masing pot perlakuan yang telah dipersiapkan sebelumnya. Kedalaman bibit padi yang ditanam berkisar $2 \mathrm{~cm}$. Dosis pupuk rekomendasi yang digunakan adalah $250 \mathrm{~kg} / \mathrm{ha}$ Urea, $50 \mathrm{~kg} / \mathrm{ha} \mathrm{SP}-36$, dan $75 \mathrm{~kg} / \mathrm{ha} \mathrm{KCl}$. Pemupukan yang dilakukan dalam penelitian ini ada tiga tahap pemberian. Tahap pertama diberikan pada saat awal penanaman yaitu pupuk Urea, SP-36 dan $\mathrm{KCl}$. Tahap kedua pemberian pupuk Urea pada saat umur tanaman padi 15 HST (hari setelah tanam). Tahap ketiga yaitu pemberian pupuk Urea pada saat umur 30 HST.

\section{Isolasi Xanthomonas oryzae pv. oryzae}

Sumber inokulum Xoo diperoleh dari tanaman padi yang terinfeksi di Kebun Percobaan Fakultas Pertanian, Universitas Syiah Kuala, Banda Aceh. Daun tanaman padi yang terinfeksi digunting dan dibersihkan terlebih dahulu dengan air aquades. Kemudian daun tersebut digunting lagi dengan ukuran $0,5 \mathrm{~cm}$ x $0,5 \mathrm{~cm}$ dan disteril dengan cara direndam di dalam alkohol $70 \%$ selama 2 menit lalu dimasukkan ke dalam air aquades. Selanjutnya daun ditiriskan di atas tissu agar air meresap.

Potongan daun yang sudah steril kemudian ditanam di atas media NA (5 g NA+250 ml aquades) dalam petridish yang sudah dipersiapkan sebelumnya. Selanjutnya diinkubasi selama 3x24 jam. Setelah 3x24 jam koloni bakteri tumbuh diisolasi kembali agar diperoleh biakan murni. Biakan murni yang telah tumbuh diambil dengan menggunakan jarum ose streril dan dipindahkan ke media miring tabung reaksi, pembiakan dilakukan selama $2 \times 24$ jam.

\section{Inokulasi Xanthomonas oryzae pv. oryzae}

Padi yang berumur $42 \mathrm{HST}$ atau memasuki fase vegetatif aktif diinokulasi dengan inokulum Xoo dengan metode Leaf Cipping (Herlina dan Silitonga, 2011) yaitu melukai daun dengan memotong secara melintang menggunakan gunting steril sepanjang $5 \mathrm{~cm}$ dari ujung daun. Selanjutnya ujung daun yang telah dipotong kemudian dirunduk dan dicelupkan ke dalam suspensi bakteri Xoo dengan kerapatan $10^{8} \mathrm{sel} \mathrm{ml}^{-1}$. Panjang daun yang dicelupkan yaitu $2 \mathrm{~cm}$. Proses perhitungan kerapatan bakteri Xoo dilakukan di Laboratorium Biologi Fakultas Keguruan dan Ilmu Pendidikan, Universitas Syiah Kuala dengan menggunakan alat Spektrofotometer.

\section{Panen}

Pemanenan dilakukan pada saat umur tanaman sudah memasuki waktu panen (110- 120 hari) yaitu ditandai dengan ciri-ciri bulir padi sudah keras, warna gabah sudah menguning dan malai masih segar.

\section{Peubah respon}

1. Pertambahan tinggi tanaman, dihitung dengan cara mengurangi tinggi tanaman padi setelah inokulasi bakteri dan sebelum inokulasi bakteri (tinggi 8 MST - 6 MST).

2. Pertambahan jumlah anakan per rumpun, dihitung dengan cara mengurangi jumlah anakan per rumpun setelah inokulasi bakteri dan sebelum inokulasi bakteri (jumlah anakan 8 MST - 6 MST).

3. Jumlah malai per rumpun, dihitung saat panen.

4. Persentase gabah berisi, dihitung dengan menggunakan rumus :

$$
\text { Gabah Berisi }=\frac{\text { jumlah gabah berisi pertanaman }}{\text { jumlah gabah total pertanaman }} \times 100 \%
$$

5. Presentase gabah hampa, dihitung dengan menggunakan rumus :

$$
\text { Gabah Hampa }=\frac{\text { jumlah gabah gabah hampa pertanaman }}{\text { jumlah gabah total pertanaman }} \times 100 \%
$$


Fajar, Lukman Hakim, Marlina, dan Efendi. Respon Beberapa Galur Padi Smart Hasil Mutasi Padi Lokal Aceh Dengan Teknologi Sinar Gamma Terhadap Xanthomonas Oryzae Pv. Oryzae Penyebab Penyakit Hawar Daun Bakteri

6. Berat gabah bernas per rumpun (g), dihitung dengan menimbang gabah berisi pada setiap tanaman setelah pemanenan pada kadar air $14 \%$.

7. Indeks panen, merupakan perbandingan bobot gabah kering isi dengan bobot kering tanaman total.

8. Produksi (ton ha ${ }^{-1}$ ).

\section{Analisis Data}

Data hasil pengamatan dianalisis dengan uji-F. Jika hasil sidik ragam terdapat pengaruh perlakuan secara nyata pada taraf $\alpha_{0,05}$ maka dilakukan uji lanjutan untuk mengetahui perbedaan antar perlakuan dengan menggunakan prosedur uji Beda Nyata Terkecil (BNT).

\section{Pertambahan Tinggi Tanaman dan Jumlah Anakan}

\section{HASIL DAN PEMBAHASAN}

Pertambahan tinggi tanaman dan jumlah anakan padi hasil mutasi radiasi sinar gamma pada padi lokal Aceh yang diamati pada umur 8 MST menunjukkan adanya pengaruh inokulasi Xanthomonas oryzae pv. oryzae terhadap pertambahan tinggi dan jumlah anakan padi. Rata-rata pertambahan tinggi dan jumlah anakan tanaman padi hasil mutasi radiasi dapat dilihat pada Tabel 2.

Tabel 2. Pertambahan Tinggi Tanaman dan Jumlah Anakan Setelah Inokulasi Bakteri Xanthomonas oryzae pv. Oryzae pada Beberapa Galur Hasil Mutasi Radiasi Padi Lokal Aceh 8 MST.

\begin{tabular}{lcc}
\hline \multicolumn{1}{c}{ Perlakuan } & $\begin{array}{c}\text { Pertambahan } \\
\text { Tinggi Tanaman }\end{array}$ & $\begin{array}{c}\text { Pertambahan } \\
\text { Jumlah Anakan }\end{array}$ \\
\hline Simeulu (USK-Snbr-M04-238-074-001) & $14.4 \mathrm{ef}$ & $9.8 \mathrm{fg}$ \\
Sisambay (USK-Snbr-M04-238-081-002) & $10 \mathrm{c}$ & $6.5 \mathrm{bc}$ \\
Sanberasi (USK-Snbr-M04-238-017-023) & $10.2 \mathrm{c}$ & $8.2 \mathrm{de}$ \\
Siteluk (USK-Snbr-M04-238-092-097) & $7.2 \mathrm{~b}$ & $9.8 \mathrm{fg}$ \\
Sibahak (USK-Snbr-M04-238-073-079) & $16.2 \mathrm{~g}$ & $11.5 \mathrm{hi}$ \\
Sulutan Unsrat-1 & $13 \mathrm{~d}$ & $12.8 \mathrm{i}$ \\
Sibabus (USK-Snbr-M04-238-110-116) & $3.7 \mathrm{a}$ & $9.8 \mathrm{fg}$ \\
Simuara (USK-Snbr-M04-238-091-097B) & $10.8 \mathrm{c}$ & $3.5 \mathrm{a}$ \\
Siluan (USK-Snbr-M04-238-058-064) & $15.5 \mathrm{fg}$ & $11.3 \mathrm{~h}$ \\
Sikuala (USK-Snbr-M04-238-114-120) & $13.7 \mathrm{de}$ & $10.5 \mathrm{gh}$ \\
UF5 & $9.8 \mathrm{c}$ & $3.5 \mathrm{a}$ \\
Sibuluh (USK-Snbr-M04-238-V1B-017) & $4.1 \mathrm{a}$ & $6.8 \mathrm{~cd}$ \\
Sialavan (USK-Snbr-M04-238-051-057E) & $14.8 \mathrm{efg}$ & $6.2 \mathrm{bc}$ \\
Snb & $12.6 \mathrm{~d}$ & $10.7 \mathrm{gh}$ \\
UF 1 & $8 \mathrm{~b}$ & $8.7 \mathrm{ef}$ \\
IRBB & $7.2 \mathrm{~b}$ & $9 \mathrm{ef}$ \\
118-(Snbr-238-112-118-180-11) & $7.3 \mathrm{~b}$ & $5.3 \mathrm{~b}$ \\
119-(Snbr-238-112-119-160-10) & $16.2 \mathrm{~g}$ & $7.2 \mathrm{~cd}$ \\
\hline
\end{tabular}

Keterangan : Angka yang diikuti oleh huruf yang sama pada kolom yang sama berbeda tidak nyata pada taraf $\alpha_{0,05}$ Uji BNT.

Tabel 2 menunjukkan bahwa galur-galur mutan yang memiliki rata-rata pertambahan tinggi yang lebih besar dijumpai pada Sibahak (USK-Snbr-M04-238-073-079), Siluan (USK-Snbr-M04-238-058-064), Sialavan (USKSnbr-M04-238-051-057E) dan 119-(Snbr-238-112-119-160-10). Sedangkan pengamatan pada pertambahan anakan terbanyak dijumpai pada galur Sibahak (USK-Snbr-M04-238-073-079) dan Sulutan Unsrat-1.

Hasil pengamatan peubah pertumbuhan pada galur Sibahak (USK-Snbr-M04-238-073-079) memperlihatkan pada stadia pertumbuhan vegetatif (pertambahan tinggi dan jumlah anakan) memiliki karakter yang konsisten. Sedangkan pada galur-galur lainnya tidak konsisten yang mana pada satu sisi pertambahan tinggi tanaman besar tapi pertambahan jumlah anakan rendah setelah diinokulasi, demikian sebaliknya. Hal ini diduga bahwa masing-masing galur yang diuji memiliki kepekaan yang berbeda terhadap serangan penyakit hawar daun. Sebagaimana dikemukakan Suryadi dan Kadir (2008), perbedaan varietas atau galur pada tanaman padi dapat menyebabkan perbedaan respon terhadap serangan penyakit HDB. Hal ini disebabkan oleh perbedaan tingkat ketahanan yang secara genetis berbeda antar varietas. Menurut Chen $d k k$., (2003) pada beberapa varietas padi bahkan bisa dijumpai perbedaan respon pada stadia tumbuh yang berbeda, ada yang tahan pada stadia vegetatif tapi dampaknya buruk pada stadia reproduktif (saat berbunga dan pembentukan biji). 
Fajar, Lukman Hakim, Marlina, dan Efendi. Respon Beberapa Galur Padi Smart Hasil Mutasi Padi Lokal Aceh Dengan Teknologi Sinar Gamma Terhadap Xanthomonas Oryzae Pv. Oryzae Penyebab Penyakit Hawar Daun Bakteri

\section{Pengaruh Xanthomonas oryzae pv. oryzae terhadap Komponen Hasil}

Hasil anaslisis ragam menunjukkan bahwa penyakit hawar daun bakteri berpengaruh nyata terhadap parameter jumlah malai, namun tidak nyata pada parameter lainnya. Rata-rata jumlah malai perumpun (JM), persentase gabah berisi (GB), persentase gabah hampa (GH) dan indeks panen (IP) disajikan pada Tabel 3.

Tabel 3. Pengamatan Komponen Hasil Pada Beberapa Galur Hasil Mutasi Radiasi Padi Lokal Aceh Akibat Penyakit Hawar Daun Bakteri (Xanthomonas oryzae pv. oryzae).

\begin{tabular}{lcccc}
\hline \multirow{2}{*}{\multicolumn{1}{c}{ Perlakuan }} & \multicolumn{3}{c}{ Komponen Hasil } \\
\cline { 2 - 4 } & JM & \% GB & \% GH & IP \\
\hline Simeulu (USK-Snbr-M04-238-074-001) & $13.66 \mathrm{a}$ & 87.46 & 5.84 & 0.51 \\
Sisambay (USK-Snbr-M04-238-081-002) & $14.00 \mathrm{ab}$ & 87.16 & 6.92 & 0.55 \\
Sanberasi (USK-Snbr-M04-238-017-023) & $20.16 \mathrm{bc}$ & 86.36 & 8.65 & 0.58 \\
Siteluk (USK-Snbr-M04-238-092-097) & $14.33 \mathrm{ab}$ & 87.32 & 6.62 & 0.44 \\
Sibahak (USK-Snbr-M04-238-073-079) & $17.00 \mathrm{ab}$ & 76.77 & 10.08 & 0.50 \\
Sulutan Unsrat-1 & $20.83 \mathrm{bc}$ & 87.00 & 5.27 & 0.47 \\
Sibabus (USK-Snbr-M04-238-110-116) & $18.16 \mathrm{ab}$ & 85.25 & 7.64 & 0.61 \\
Simuara (USK-Snbr-M04-238-091-097B) & $14.16 \mathrm{ab}$ & 80.69 & 6.74 & 0.55 \\
Siluan (USK-Snbr-M04-238-058-064) & $16.33 \mathrm{ab}$ & 89.17 & 6.48 & 0.67 \\
Sikuala (USK-Snbr-M04-238-114-120) & $19.00 \mathrm{ab}$ & 86.92 & 5.69 & 0.56 \\
UF5 & $25.50 \mathrm{c}$ & 84.30 & 10.15 & 0.50 \\
Sibuluh (USK-Snbr-M04-238-V1B-017) & $25.50 \mathrm{c}$ & 87.36 & 6.65 & 0.49 \\
Sialavan (USK-Snbr-M04-238-051-057E) & $17.67 \mathrm{ab}$ & 74.69 & 8.98 & 0.55 \\
Snb & $16.83 \mathrm{ab}$ & 82.55 & 11.11 & 0.63 \\
UF 1 & $21.50 \mathrm{bc}$ & 88.43 & 8.83 & 0.58 \\
IRBB & $17.67 \mathrm{ab}$ & 85.00 & 6.68 & 0.59 \\
118-(Snbr-238-112-118-180-11) & $20.50 \mathrm{bc}$ & 87.06 & 10.01 & 0.53 \\
119-(Snbr-238-112-119-160-10) & $18.83 \mathrm{ab}$ & 82.10 & 9.43 & 0.56 \\
\hline
\end{tabular}

Keterangan : Angka yang diikuti oleh huruf yang sama pada kolom yang sama berbeda tidak nyata pada taraf $\alpha_{0,05}$ Uji BNT.

Tabel 3 menunjukkan bahwa jumlah malai tertinggi dijumpai pada perlakuan UF5 dan Sibuluh (USK-SnbrM04-238-V1B-017). Namun demikian, antara galur UF5 dan Sibuluh (USK-Snbr-M04-238-V1B-017) dengan 16 galur lainnya memberi respon yang sama terhadap penyakit hawar daun pada pengamatan persen gabah berisi, persen gabah hampa dan indeks panen.

Tingginya jumlah malai tampak tidak berhubungan dengan persen gabah berisi dan persen gabah hampa serta indeks panen. Tiga peubah ini kemungkinan lebih ditentukan oleh tingkat ketahanan masing-masing galur. Sehingga bisa dikatakan bahwa sebanyak 18 galur yang diuji mempunyai tingkat ketahanan yang sama terhadap serangan penyakit hawar daun.

\section{Pengaruh Xanthomonas oryzae pv. oryzae terhadap Hasil Panen}

Representasi hasil hanen diukur pada hasil panen per rumpun dan produksi panen per hektar. Hasil anaslisis ragam menunjukkan bahwa penyakit hawar daun tidak berpengaruh terhadap hasil panen per rumpun dan produksi per hektar. Rata-rata hasil panen per rumpun dan produksi per hektar disajikan pada Tabel 4. 
Fajar, Lukman Hakim, Marlina, dan Efendi. Respon Beberapa Galur Padi Smart Hasil Mutasi Padi Lokal Aceh Dengan Teknologi Sinar Gamma Terhadap Xanthomonas Oryzae Pv. Oryzae Penyebab Penyakit Hawar Daun Bakteri

Tabel 4. Hasil Panen per Rumpun dan Produksi Pada Beberapa Galur Hasil Mutasi Radiasi Padi Lokal Aceh Akibat Penyakit Hawar Daun Bakteri (Xanthomonas oryzae pv. oryzae).

\begin{tabular}{|c|c|c|}
\hline Perlakuan & $\begin{array}{l}\text { Hasil Panen } \\
\left(\text { g rumpun }^{-1}\right)\end{array}$ & $\begin{array}{l}\text { Produksi } \\
\left(\text { ton ha }{ }^{-1}\right)\end{array}$ \\
\hline Simeulu (USK-Snbr-M04-238-074-001) & 55.50 & 9.81 \\
\hline Sisambay (USK-Snbr-M04-238-081-002) & 48.41 & 8.85 \\
\hline Sanberasi (USK-Snbr-M04-238-017-023) & 52.68 & 9.81 \\
\hline Siteluk (USK-Snbr-M04-238-092-097) & 44.04 & 8.11 \\
\hline Sibahak (USK-Snbr-M04-238-073-079) & 35.92 & 7.36 \\
\hline Sulutan Unsrat-1 & 36.73 & 6.72 \\
\hline Sibabus (USK-Snbr-M04-238-110-116) & 45.69 & 8.53 \\
\hline Simuara (USK-Snbr-M04-238-091-097B) & 37.26 & 7.04 \\
\hline Siluan (USK-Snbr-M04-238-058-064) & 55.52 & 9.92 \\
\hline Sikuala (USK-Snbr-M04-238-114-120) & 44.97 & 8.11 \\
\hline UF5 & 54.85 & 10.40 \\
\hline Sibuluh (USK-Snbr-M04-238-V1B-017) & 48.02 & 8.75 \\
\hline Sialavan (USK-Snbr-M04-238-051-057E) & 46.35 & 8.85 \\
\hline Snb & 60.22 & 11.41 \\
\hline UF 1 & 69.17 & 12.48 \\
\hline IRBB & 39.32 & 7.36 \\
\hline 118-(Snbr-238-112-118-180-11) & 67.65 & 12.43 \\
\hline 119-(Snbr-238-112-119-160-10) & 45.90 & 8.85 \\
\hline
\end{tabular}

Keterangan : Angka yang diikuti oleh huruf yang sama pada kolom yang sama berbeda tidak nyata pada taraf $\alpha_{0,05}$ Uji BNT.

Respon yang sama antar galur yang diuji sebagaimana dapat dilihat pada Tabel 4 juga mengindikasikan sifat genetis antar galur dalam merespon serangan penyakit hawar daun memiliki ketahanan yang sama. Tampak bahwa hasil panen per rumpun dan produksi padi per hektar tidak menunjukkan perbedaan yang signifikan.

Tingginya intensitas serangan penyakit hawar daun dapat menentukan tingkat kerugian hasil panen (Tasliah. 2012). Pada kondisi intensitas serangan yang rendah, efeknya terhadap hasil panen mungkin tidak signifikan, hal ini terjadi pada varietas padi yang mempunyai tingkat toleransi yang tinggi (CABI, 2008).

\section{KESIMPULAN}

Berdasarkan hasil pengamatan menunjukkan bahwa perbedaan respon sebanyak 18 galur hasil mutasi radiasi padi lokal Aceh terhadap penyakit hawar daun memiliki perbedaan yang signifikan pada pertambahan tinggi dan jumlah anakan serta jumlah malai. Pada pengamatan persen gabah berisi, persen gabah hampa, hasil panen per rumpun dan produksi per hektar, pengaruh penyakit hawar daun tidak signifikan:

\section{DAFTAR PUSTAKA}

Anggraini, F., A. Suryanto, dan N. Aini. 2013. Sistem tanam dan umur bibit pada tanaman padi sawah (Oryza sativa L.) varietas Inpari 13. Jurnal Produksi Tanaman $1: 2$.

Badan Pusat Statistik (BPS). 2018. Tanaman Pangan. www.BPS.go. id. Diakses tanggal 11 September 2018.

CABI. 2008. Xanthomonas oryzae. Bulletin CABI and EPPO for the EU. Pp. 8.

Chen S, Xu CG, Lin XH and Zhang Q . (2003). Improving bacterial blight resistance of 6078, an elite restorer line of hybrid by molecular marker assisted selection. Plant Breed.120: 133-137.

Herlina, L. dan T.S.Silitonga, 2011. Seleksi lapang ketahanan beberapa varietas padi terhadap infeksi hawar dan bakteri strain IV dan VII. Buletin Plasma Nutfah. 17(2).

Hifni, H.R. dan M.K. Kardin. 1998. Pengelompokan isolat Xanthomonas oryzae pv. oryzae dengan menggunakan galur isogenik padi IRRI. Hayati 5:66- 72 .

Ogawa, T. 1993. Methods and strategy for monitoring race distributions and identifications of resistance genes to bacterial leaf blight (Xanthomonas campestris pv. oryzae) in rice. JAEQ 27:71-81. Ou, S. H. 1985. Rice Diseases. ( $2^{\text {nd }}$ ed) CMI Kew. 380 p.

Ou, S.H. 1985. Rice diseases (2nd ed) CMI Kew.380 pp.

Sudir, B., Nuryanto. dan S.K.Triny. 2012. Epidemiologi, patotipe, dan strategi pengendalian hawar daun bakteri pada tanaman padi. IPTEK Tanaman Pangan.7(2):79 - 87. 
Fajar, Lukman Hakim, Marlina, dan Efendi. Respon Beberapa Galur Padi Smart Hasil Mutasi Padi Lokal Aceh Dengan Teknologi Sinar Gamma Terhadap Xanthomonas Oryzae Pv. Oryzae Penyebab Penyakit Hawar Daun Bakteri

Suparyono. Sudir dan Suprihanto. 2004. Komposisi patotipe patogen hawar daun bakteri pada tanaman padi stadium tumbuh berbeda. Jurnal Penelitian Tanaman Pangan. 22(1) : 45-50. Jakarta.

Suryadi, Y. dan T.S. Kadir. 2008. Kajian infeksi Xanthomonas oryzae pv. oryzae terhadap beberapa genotipe padi : hubungan kandungan hara dengan intensitas penyakit. Ilmu Pertanian. 15(1) : $26-36$.

Song J.Y., D.S Kim, M.C. Lee, K.J. Lee, J.-B.Kim, S.H, B.-K.Ha, S.J. Yun, and S,Y. Kang. 2012. Physidogical characterization of gamma-ray induced salt tolerant rice mutant. Australian Journal of plant Science, 6(3) : 421-429.

Tasliah. 2012. Gen ketahanan tanaman padi terhadap bakteri hawar daun, jurnal litbang pertanian. Vol. 31 No. 3 September 2012: 103 - 112 . 